Review article

DOI: $10.22363 / 2313-1683-2019-16-2-224-236$

UDC 159.99

\title{
Psi Chi at 90 Years: The International Honor Society in Psychology
}

\author{
Harold Takooshian \\ Fordham University \\ 113 W. 60th St., New York, NY 10023, United States of America
}

\begin{abstract}
In 2019, Psi Chi celebrates its 90th and 10th birthdays as the National and International Honor Society in Psychology. This review of the glorious history of Psi Chi is in three parts: (1) its current mission, serving over 750000 life members in 1130 college campuses world-wide; (2) its humble but inspiring origins in 1929 at Yale University; (3) four points of impressive courage within the history of Psi Chi - in 1929, 1959, 1981, and 2009; and also includes a bibliography, for international and U.S. readers to access prior histories of Psi Chi.
\end{abstract}

Key words: Psi Chi; Psi Beta; National Honor Society in Psychology; International Honor Society in Psychology; international psychology; history of psychology

\section{Introduction}

In 2019, psychology students and faculty world-wide have reason to celebrate two momentous anniversaries: 90 years of Psi Chi, formed on September 4, 1929, and, since 2009, its 10 years as the International Honor Society in Psychology.

How did Psi Chi become, by some measures, the world's largest honor society, touching the lives of over 750000 life members in over 1130 chapters world-wide? This article offers a panoramic review of the glorious 90 year history of Psi Chi and, in particular, four points where it showed bold courage, to become the glorious Society that it is today.

Those who learn of the glorious history of Psi Chi may be inspired at many turns: (a) how the original idea was conceived in 1927 in a basement in Kansas; (b) how quickly this humble idea spread to national popularity by 1929, despite some resistance; (c) how this idea drew together so many brilliant faculty and students over the years, to further develop it into so many life-changing programs; (d) how so many thousands of students and faculty lives today (both inside and outside the Society) have been deeply touched by its many awards, grants, conferences, chapter and other activities; (e) not least of all, how this huge Society thrives without charging a penny in dues after a new member is inducted for life.

(C) Takooshian H., 2019

This work is licensed under a Creative Commons Attribution 4.0 International License 
Are Psi Chi members familiar with this rich history? Sadly, we find few U.S. Psi Chi members know much about the glorious history of their Society (Takooshian, 1999). Since 2009, might new international members be even less familiar?

Happily, we have many diverse and inspiring histories of Psi Chi, written by past leaders - some of these easily available on the Internet. A list of citations appears below. These histories include anniversary publications to mark 50 years (Hunt, 1979) and 75 years (Hogan \& Takooshian, 2004), an edited volume (MacKinney, 1986), an oral history (Davis \& Wertheimer, 2000), an international report (Takooshian \& Newman, 1998), a video that is now online (Karlin, 1998) and, not least of all, two rich historical essays (Cousins, Tracy, \& Giordano, 1992; Hogan \& Sexton, 1993).

On this $90^{\text {th }}$ and $10^{\text {th }}$ anniversaries of the National and International Honor Society in Psychology, this four-part report reviews: (a) the mission of Psi Chi; (b) its unique origin and history; (c) four points of bold courage in this history; (d) and now its global future.

\section{Psi Chi Mission}

The mission of Psi Chi is stated succinctly in its induction ceremony, as well as its constitution, website and video (Karlin, 1998): "The purpose of Psi Chi shall be to encourage, stimulate, and maintain excellence in scholarship of the individual members in all fields, particularly in psychology, and to advance the science of psychology" (www. psichi.org).

Over the years, Psi Chi has found increasingly diverse ways to achieve this mission, through its conferences (local, regional, national, and now international), publications (newsletter, student journal), Internet resources, and promotion of research, internships, and service projects. Thanks to a series of Psi Chi Hunt Awards (Takooshian, 1999), past research has found and documented many facts about Psi Chi. For example: (a) hundreds of eminent U.S. psychologists today began their psychology careers through Psi Chi, agreeing with APA Past-President Raymond Fowler that "As a student, Psi Chi put me in closer contact with faculty, and strengthened my decision to become a psychologist" (Heitner \& Denmark, 2000, p. 14); (b) Psi Chi is by far the world's single largest sponsor of student research (Takooshian, Velayo, and Prohaska, 2002), now topping \$400000 in grants per year; (c) many Psi Chi programs have deeply touched the lives and careers of thousands of students who offered their first presentations at a Psi Chi conference (Carmody, 1998; Young \& DaPrada, 1998).

In 2010, Past-President Alvin Wang stated this crisply: "Psi Chi continues to be a vibrant, growing community of scholars. Last year we inducted 21578 new members, and in so doing broke the 600000 member mark... in 1102 chapters. While we were pleased that $\$ 183359$ in grants and awards was distributed to our members, I hope we will greatly increase levels of this important form of support in the future" (Wang, 2010, p. 6).

\section{Psi Chi Origins in 1927}

Though we mark September 4, 1929, as the "birth" of Psi Chi at Yale, the idea for the Society was "conceived" two years earlier in a very different place. Its fascinating history 


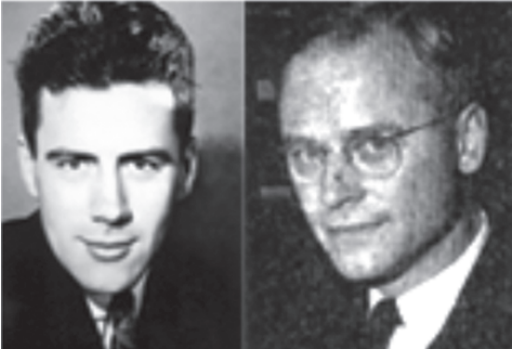

Figure 1. Undaunted: Edwin B. Newman and Frederick Howell Lewis

necessarily begins in late 1927, when two student researchers shared a hot drink late one night in a basement lab at the University of Kansas. Masters student Frederick Howell Lewis told undergraduate Edwin Broomell Newman how psychology lacks a national student fraternity like many other fields have (Figure 1). "Eddie" Newman asked "Bud" Lewis if they can be the ones to start one? Newman and Lewis organized three meetings in May of 1928 (in Madison WI), December of 1928 (at Columbia University), and May of 1929 (in Urbana, IL), where students decided to form a "National Graduate Council for a Psychology Fraternity", and to conduct a national survey on this question. Lewis later recalled "[T]his 22-year-old graduate student had the nerve in the spring of 1928 to address an inquiry to all the moguls of psychology - names I saw in gold lettering on the covers of formidable tomes on the library shelves... [In our survey,] a few replied 'Great' - a few said 'Nuts' - and most were lukewarm. Undaunted, as kids are, Eddie Newman and I were undismayed by the enthusiastic indifference" (Lewis, 1969, p. 7).

In over 100 replies to their survey, they found an even split: one-third of students and faculty loved the idea of a national psychology student group, one-third were indifferent, and one-third were opposed. No one was more opposed than Harvard Professor E.G. Boring, who famously returned a scathing three-page letter refusing to circulate their survey at Harvard, and urging the two students to stop immediately their efforts "to start another abortive, debilitating organization" (Boring, in Davis \& Wertheimer, 2000, p. 11).

What to do?

\section{Four Points of Bold Courage in Psi Chi History}

\section{1929: Two Courageous Students}

At their May, 1929 meeting in Illinois, students were undaunted, drafted a constitution, and voted to meet in September at Yale, during the Ninth International Congress of Psychology on September 1-7 (Figure 2). For seven days that Labor Day week, these students were part of what some regard as the greatest scientific meeting in the 140-year history of psychology. This was the first international congress on American soil, including 1050 participants: 722 U.S. psychologists and students from all 48 states, 104 international psychologists from 21 nations, plus 96 spouses and 129 guests.

Undaunted, the students met on September 3, then reconvened on September 4 to sign the charter that formed their society. Representatives of 14 schools signed the charter, and eight others joined by December 31, 1929 - totaling 22 charter chapters. The society's original name was Sigma Pi until the preferred name of Psi Chi became available in 1930.

Psi Chi met annually, starting in 1930 in Iowa City, and grew slowly yet steadily launching a Newsletter in 1931, publishing a handbook, generating ideas for new projects, and attracting many brilliant young leaders like Ruth and J.P. Guilford (Hogan, 2001). 
By its fifth anniversary in 1934, Psi Chi had 612 individual members in 27 chapters. By its tenth anniversary in 1939 at Stanford, it chartered 34 chapters, then 69 chapters by 1949 in Denver.

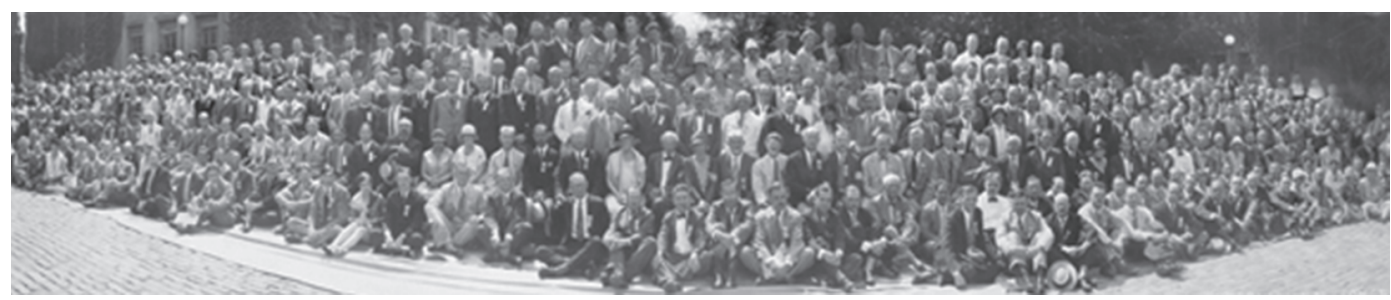

Figure 2. In 1929, the Ninth International Congress of Psychology at Yale University

During the 1950s, the American Psychological Association (APA) sought greater involvement with a student organization, and agreed to provide much-needed space for Psi Chi to create its first true national headquarters, in the APA building in Washington DC. In 1955, the last act of Psi Chi's out-going Executive Secretary Louise Forer was to ship all her Psi Chi boxes to the incoming Executive Secretary Meredith Marks, to open the Psi Chi office in 1956. But times remained hard for Psi Chi in the 1950s. In 1954, Psi Chi raised its lifetime fee from $\$ 3$ to $\$ 5$ to make ends meet (since Psi Chi never charges dues), yet costs were rising, and the survival of the Society was increasingly questionable when Dr. Marks resigned after two years, in the fall of 1958.

What to do?

\section{1959: A "Single Mom" and The Courage to Expand}

Looking back, 1959 proved a watershed year for Psi Chi. To replace Dr. Marks in 1958, George Washington University Professor Eva Johnson turned to her student Ruth Hubbard Cousins. Ruth was a talented and gracious 38-year-old graduate student who began college at Duke in 1940, and was now completing her masters in psychology at GWU. Ruth was reluctant, because she was married with two daughters, and needed to focus on her masters (Figure 3). But Ruth's husband James F. Cousins, CPA, was a respected accountant in Washington DC who encourage Ruth to say yes, even offering to donate his financial skills to help Psi Chi rebound. Based on this, Ruth agreed to a limited one-year appointment, at $\$ 3000$ for the year. During this year, the couple made great headway together, improving the Society's book-keeping and cash flow, filing IRS tax forms properly, and redesigning the Newsletter. Ruth was set to resign later in 1959 during the APA meeting in Cincinnati.

But life intervened. On Labor Day weekend in September of 1959, (exactly 30 years after the 1929 Congress), Ruth had to rush Jim to Doctors Hospital with a ruptured appendix. Due to a botched surgery, her beloved Jim died a week later, on September 14, 1959. Ruth was suddenly a single mother raising two young daughters.

What to do?

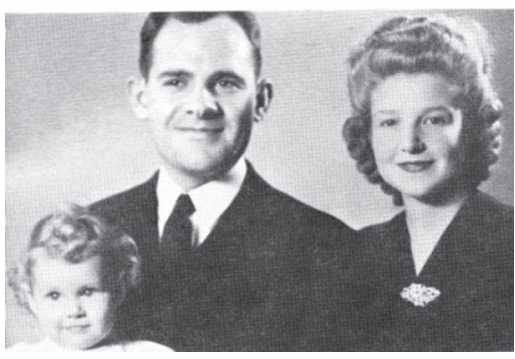

Figure 3. Ruth and Jim Cousins with their daughter Carol 
With great courage, Ruth decided to remain with Psi Chi, hopeful that she and her Cousins girls could find ways to help expand Psi Chi. Young Carol learnt to type, Joan excelled at filing, and their mom Ruth was full of plans. One cannot help but be moved by the touching oral histories given by a single mom and her loving daughter Carol, who sacrificed to keep Psi Chi alive and healthy (Davis \& Wertheimer, 2000, pp. 35-44). This marked the start of Ruth's legendary 33 years of brilliant service to Psi Chi, from 19581991. At first, Psi Chi leadership ignored Ruth's innovative ideas. But soon, incoming Presidents Wayne Dennis (1960-1962) and Roger Russell (1962-1964) were very receptive, encouraging Ruth's two efforts.

First, to expand Psi Chi, by collaborating with APA and other organizations. In 1958, APA Council approved Psi Chi as its first APA “affiliate organization”, giving Psi Chi program time at its annual meetings, space in its periodicals, and access to its resources. Under Cousins, Psi Chi began inviting eminent psychologists to meet with students during APA - like B.F. Skinner, Albert Bandura, Carl Rogers. One of the first in 1960 was E.G. Boring of Harvard, who agreed to visit APA as Psi Chi's invited speaker, voicing his high praise for the student group he attacked in 1928. Psi Chi increasingly encouraged student research, and issued certificates to outstanding students and faculty.

Second, to convert Psi Chi from an "honorary society" (which simply recognizes past achievements) into an "honor society" (which also promotes future achievements). Under Cousins, Psi Chi carefully revised its constitution and membership policies to qualify for election into the Association of College Honor Societies (ACHS) in 1965 as "the National Honor Society in Psychology". When anyone occasionally criticized Psi Chi as an "elitist" organization that deliberately excludes most students, Cousins' two-fold reply was: (a) most Psi Chi activities like the distinguished lectures benefit non-members as well, and (b) everyone is equally eligible to join the Society based on merit, regardless of their ethnicity, gender, disability, or other demographics.

Through the 1960s and 1970s, as the psychology major swelled to record numbers on U.S. college campuses, so also did the number of Psi Chi chapters and individual members - totaling 81812 life members in 361 chapters by 1974. Each year, Cousins' office registered over 3000 new members and over a dozen new chapters. Cousins' annual reports increasingly noted that Psi Chi was now thriving in every way - its numbers, programs, and finances - with just one exception. That one exception was students at two-year colleges. The national office received a steady flow of calls from psychology students at two-year colleges who wanted to join Psi Chi. But the ACHS had a clear policy barring students at two-year schools, so Psi Chi had to turn these deserving students away, despite their achievements and interest in Psi Chi membership.

What to do?

\section{1981: The Courage to Include The Excluded}

Starting in 1977, Cousins engaged her daughter Carol to look into a new society for two-year colleges. In 1980, in U.S. higher education, there were 1957 four-year schools teaching 6000000 students, compared with 1274 two-year schools teaching 4525000 students, so over $40 \%$ of U.S. students are in community or two-year colleges with no ACHS honor societies. Though ACHS rules prevented Psi Chi chapters at two-year 
colleges, Psi Chi Council did not want to continue to exclude outstanding two-year psychology students.

So in 1981, with Carol Tracy (Figure 4) as its Executive Director, Psi Beta was officially chartered and incorporated in Carol's home town of Chattanooga, Tennessee, as "The National Honor Society in Psychology for Two Year Colleges", with the same mission as Psi Chi. Psi Beta quickly elected a National Council, launched its new logo and Newsletter, and soon attracted thousands of

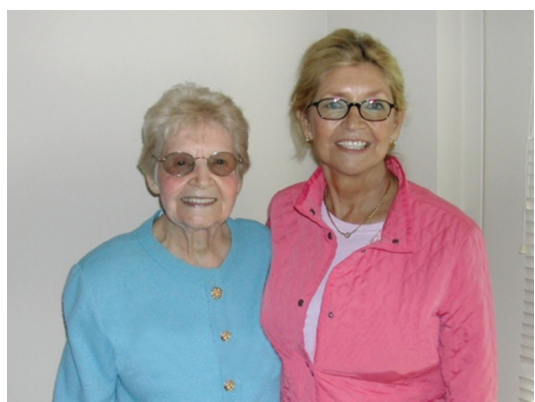

Figure 4. Executive Officers Ruth H. Cousins and Carol Tracy previously excluded two-year students and faculty. Like Psi Chi, Psi Beta was accepted as an affiliate of APA, and grew steadily, with 24 chapters by 1983, 50 chapters in 1987, and 80 chapters with 4500 members for its 10th anniversary in 1991.

By 1992, seeing the success of Psi Beta, the ACHS itself "made history" by following the lead of Psi Beta to repeal its exclusion of two-year schools, and electing Psi Beta as the first ACHS-approved honor society for two-year schools. Psi Beta now continues to flourish past its 35th anniversary in 2016, under a series of dedicated Executive Directors: Carol Tracy, Ann Ewing, Jerry Rudmann, and now Valerie Smith Senatore (www.psibeta. org).

The APA meeting in 1991 was an unusually joyous event. It marked not only 10 years of Psi Beta, but also the retirement of Ruth Cousins after 33 years as Executive Director from 1958-1991, and the debut of Kay Wilson as Cousins' successor. At her final APA meeting, Cousins was celebrated with an APA Presidential Citation, and Bud Lewis agreed with his friend Eddie Newman, that "Far more than most people recognize, Psi Chi is not what we founded, it is what you have made it" (Hogan \& Sexton, 1993, p. 200).

By 1991, Cousins was beloved across her many large circles - Psi Chi, Psi Beta, APA, ACHS, ASAE, the National Press Club, and Washington DC (Hogan, 2009). She was "as wise as a serpent, and gentle as a dove" (Matthew 10:16) - gracious to all, yet too clever to be manipulated by even the most powerful people. After Alfred and Dorothy Takooshian (the parents of a future Psi Chi President) spent three hours with Cousins, Alfred told his son "Harold, Ruth Cousins is as close as this nation comes to producing American Royalty". Whether we call this "Southern charm" or Christian Caritas, this joyous woman brought joy to all around her, with one exception below.

Cousins told friends that when Jim lay ill in Doctors Hospital in 1959, he wanted her to promise that she would remarry if he did not make it, so she would not deny to another man the great joy that she brought to Jim. But for 42 years, from his death in 1959 till her death on January 11, 2007, this single mother explained to the many adoring men around her that her beloved Jim was a proud Navy veteran buried in Arlington National Cemetery, so Ruth could never remarry if she wanted to be buried beside her Jim. On the Internet today, we can view the gravestones of Jim and Ruth Cousins, side by side in Arlington for eternity.

Following Cousins, Kay Wilson (Figure 5) was the Executive Officer of Psi Chi for 12 years, from 1991 till her untimely death from cancer on 2003, at age 63. Like Cousins, Wilson brought her own unique gifts to Psi Chi, raising it to new heights - its magazine, 


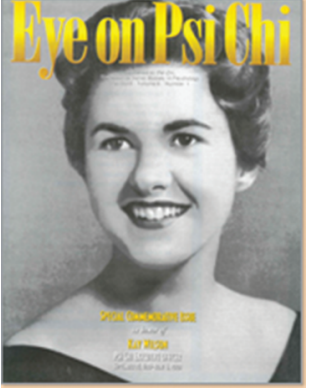

Figure 5. Executive Officer Kay Wilson

awards, conference programs. Under Wilson, Psi Chi more than doubled in membership in 12 years - from 221573 members in 734 chapters in 1991, up to 445361 members in 1013 chapters in 2003. Though Psi Chi income is based squarely on its members' one-time fee, the Society under Wilson tripled its revenues in six years, holding a hefty $\$ 4000000$ in assets by 1997. With boundless energy, Wilson was elected the President of the ACHS for 2003.

As Wilson proudly noted in 1998, Psi Chi had excelled to number-one in many ways: it was by far the world's largest psychology membership organization (with over 500000 life members), the world's largest honor society in any field (based on its $1000+$ chapters), the outstanding non-profit organization in the USA with a small staff of five or fewer people (judged by the ASAE, the American Society of Association Executives), and "more psychologists have been through the doors of Psi Chi than of any other psychological association in the world" (Karlin, 1998).

Two inspiring special issues of the Psi Chi magazine are available online, celebrating the legacy of Ruth H. Cousins (edited by Kay Wilson, 1991), and then Kay Wilson (edited by Daniel P. Bockert, 2003).

\section{2009: The Courage to Expand World-Wide}

In recent years, some Psi Chi officers felt increasingly uneasy that non-USA students were excluded from the Psi Chi family. Psychology today is now a global field, with 75\% of the world's psychologists living outside the USA (Zoma \& Gielen, 2015). Moreover, barely 10 percent of U.S. psychologists had international interests; it took 21 years (from 1976 until 1997), for APA to find enough psychologists (810) to finally approve a Division of International Psychology in 1997 (Takooshian \& Bais, 2017).

But this is less true of Psi Chi - which "has a long history of international involvement" (Zlokovich, 2012, p. 6). Not only was Psi Chi born at the 1929 International Congress, but a surfeit of Psi Chi officers had international credentials. For example, in the 1930s, Eddie Newman spent a year in Germany with Max Wertheimer before returning to Harvard to complete his doctorate in 1934. In the 1940s, Psi Chi President Florence L. Goodenough (1945-1948) had previously served in 1942-1943 as the founding President of what is now the International Council of Psychologists (O'Roark, 2018). At least half of Psi Chi Presidents over the decades were widely known as international leaders (like Roger W. Russell in the 1960s, Florence Denmark in the 1970s, Virginia S. Sexton in the 1980s).

Table lists some international developments within Psi Chi. In 1963, President Roger Russell dedicated The Psi Chi Newsletter to "the International Year of Psychology", inviting students from a score of nations to write about psychology in their homeland. In 1964, Cousins toured psychology around the world at the invitation of the ICP.

Much later, in 1994, Psi Chi President Joseph Horvat appointed a new "International Committee" to explore possibilities. Its Chair Harold Takooshian partnered with Joan Buchanan of the APA Office of International Affairs to survey all 75 national psychology 
associations, with three results: (1) fewer than half of the surveys were returned; (2) of these, barely $20 \%$ of the associations allowed students as affiliate members (as APA does), preferring that that students wait to finish their degree; (3) not a single nation outside the USA has a national student group, and the concept of a national student honor society was simply unknown outside the USA.

\section{The Internationalization of Psi Chi: A Timeline}

$\begin{array}{ll}1929 & \text { The Ninth International Congress of Psychology, New Haven CT (Sept. 1-7) } \\ 1963 & \text { Psi Chi International Year of Psychology } \\ 1964 & \text { Ruth Cousins tours the world with the International Council of Psychologists } \\ 1985 & \text { A new Psi Chi bylaw introduced "international affiliate chapters" } \\ 1994 & \text { Psi Chi Council appoints a new committee on international psychology. } \\ & \text { The International Committee speaks at ICP in Lisbon, Portugal } \\ 1995 & \text { The Psi Chi Council meets in the United Nations headquarters in New York City } \\ 1996 & \text { Psi Chi Mini-Convention \#2 is held in Canada at the University of Toronto } \\ 1997 & \text { APA charters its new International Division (52) under President Ernst G. Beier } \\ 1999 & \text { A Psi Chi article in the International Journal of Psychology. } \\ & \text { President Slater Newman launches a quarterly column on "International Notes" } \\ 2000 & \text { Psi Chi Council meets in San Juan, Puerto Rico. } \\ 2003 & \text { Formation of IPSO, the International Psychology Student Organization } \\ 2009 & \text { Psi Chi chapters vote to become the "International Honor Society of Psychology" }\end{array}$

Based on this, and with no funding, Takooshian visited the ICP meeting in Lisbon in 1994, to tell colleagues and students what they were missing, with a data-based message on "The impact of a student honor society on a nation's psychology" (Takooshian, 1994). Sadly, the entire audience consisted of just one American professor. Happily, this one professor was the legendary John M. Davis, who was the incoming Secretary-General of ICP (1994-1997) and later President of Psi Chi (2006-2007). The two discussed specific ways to open international colleagues to the Psi Chi concept.

In 1997, the International Journal of Psychology (IJP) Editor Merry Bullock invited a detailed article about Psi Chi for the IJP (Takooshian \& Newman, 1998). In 1998, Newman launched "International Notes" as a quarterly column in the Eye on Psi Chi. The co-authors also organized what proved to be a fecund session at APA in Boston on August 21, 1999, for the 70th anniversary of Psi Chi, on "An international psychology group for psychology: Desirable? Feasible?" From this panel, four bold students in four nations joined to launch the International Psychology Students' Organization (IPSO) in 2003. These four were Edward Van Rossen of Belgium, Shannon McCaslin of the USA, Nana Owusu-Banahene of Ghana, and Malin G. Wiking of Denmark (Van Rossen et al., 2003).

Despite such international activities, Psi Chi itself hesitated to "go global". Back in 1985, Psi Chi added "international affiliate chapters" to its bylaws, and even approved the first non-USA school - the University of British Columbia in Canada. But the school 
never installed its chapter, due to the unfavorable currency conversion that year. At the same time, the ACHS actively discouraged its U.S. honor societies to "go global", due to all the problems of language, currency, culture, distance.

President John M. Davis (in press) recently shared his "inside story" of how he carefully collaborated for years with others, to secure a majority of voting Psi Chi chapters in 2009, for the pivotal vote to approve the "International Honor Society in Psychology". Now, the fast-growing number of psychology students in other nations are eligible to join the Psi Chi family, and reap all its benefits. Of course, this now opens vast new horizons for Psi Chi. As of 2019, an estimated 151 million students in 193 nations study at 17000 universities across Europe (4000 universities), North America (3400), Latin America (1300), India (1600), China (1200), Russia (1000), Japan (800), Africa (600), Australia (100), and elsewhere. Though the Psi Chi Board has not yet surveyed its international chapters, many are clearly thriving (Novikova et al., 2019).

Sadly, progress is slow, with barely 20 international chapters these past 10 years about half of the number of "Psi Chi International Ambassadors" (35) appointed to "spread the word" (Takooshian, 2013). In 2010, Executive Officer Martha Zlokovich proposed a 50-page "Strategic Plan for International Expansion". In 2013, thanks to President Mercedes McCormick's program of "Building Bridges” between Psi Chi and international psychology, an experienced team of seven leaders outlined a thoughtful roadmap to globalize Psi Chi, published in the RUDN Journal of Psychology and Pedagogics (McCormick et al., 2014).

Though progress is slow, the potential is there - beyond the wildest dreams of Newman, Lewis, Cousins, or Wilson, for even greater achievements yet to be.

\section{Looking Back}

Ninety years after 1929, we continue to see two lingering ironies about these two courageous young students - Newman and Lewis.

First, about them. Each went on to a long and celebrated career. Bud Lewis (19062000) taught at Bates College and Harvard, before becoming the esteemed Director of the New York Herald Tribune Fresh Air Fund for over a quarter-century. Eddie Newman (1908-1989) had a distinguished career, including the Recording Secretary of the American Psychological Association and a Professor and Chair of the Psychology Department at Harvard. Yet any search of these two will find that they are most celebrated as the two students who co-founded Psi Chi. Fortunately, both Lewis and Newman were able to join Ruth Cousins (1920-2007) in 1979, to celebrate the 50th anniversary of their joint creation.

Second, about Psi Chi. Some consider the Ninth International Congress of Psychology at Yale as the greatest assembly of psychologists in history. Indeed, the Congress' August 535-page program lists a "who's who" of luminaries from 22 nations (Takooshian \& Salovey, 2004). This book makes no mention at all of any student group, except for a handful of students' names scattered among the index of 826 participants - like Anne Anastasi (Columbia University), Ernest R. Hilgard (Yale University), M.H. Lewis (University of Kansas), and Edwin Newman (University of Kansas). Yet nearly every five years since 1999, distinguished psychologists from many cities converge on the stately 
Presidents Room at Yale University on September 4, less to speak of past luminaries, but more to celebrate Psi Chi and the overlooked students who quietly created it in 1929.

Thanks to their youthful determination in 1929, tens of thousands of student and faculty lives have been touched across the USA, and now the world.

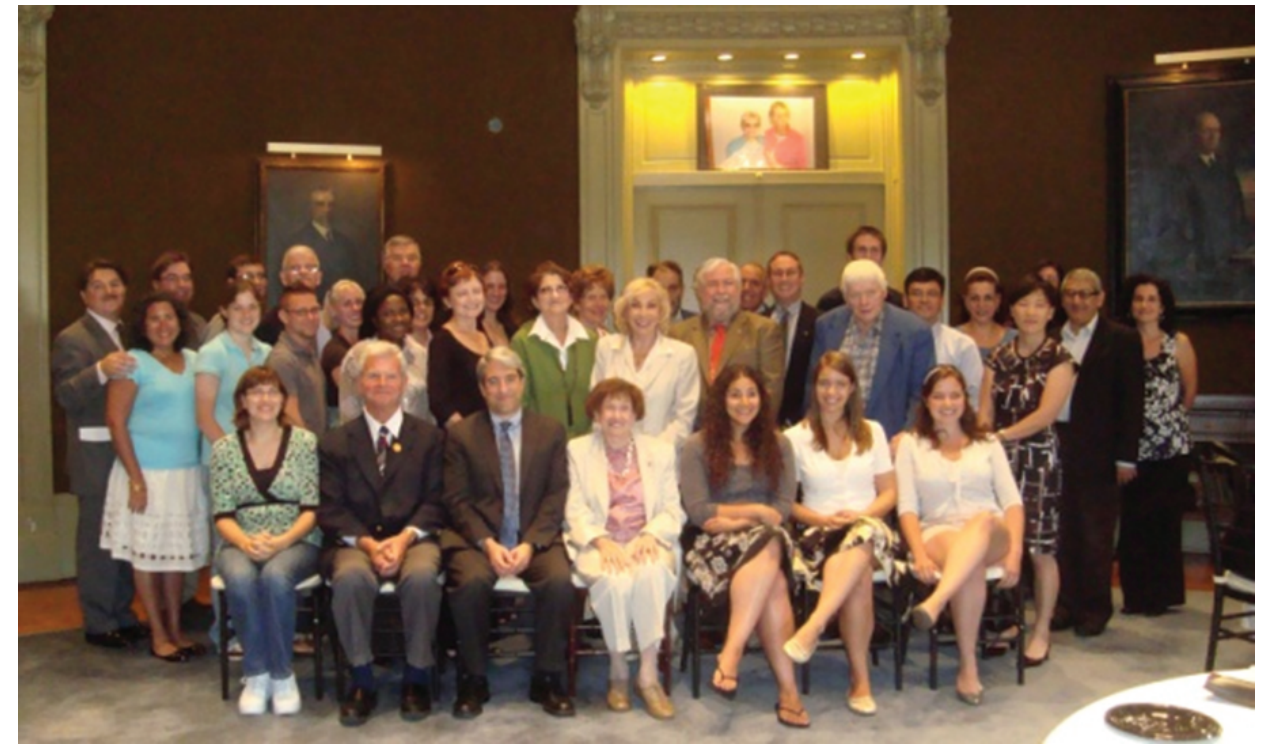

Figure 6. In 2009 at Yale, celebrating 80 years of Psi Chi

\section{Bibliography of Histories of Psi Chi}

Cousins, R.H., Tracy, C., \& Giordano, P.J. (1992). Psi Chi and Psi Beta: The two national honor societies in psychology. In A.E. Puente, J.R. Matthews, \& C.L. Brewer (Eds.), Teaching psychology in America: A history (pp. 403-427). Washington DC: American Psychological Association.

Davis, S.F., \& Wertheimer, M. (Eds.). (2000). An oral history of Psi Chi, the National Honor Society in Psychology. Chattanooga TN: Psi Chi.

Hogan, J.D., \& Sexton, V.S. (1993). Psi Chi, the National Honor Society in Psychology. In J.L. Pate \& M. Wertheimer (Eds.), No small part: A history of regional organizations in American psychology (pp. 189-203). Washington DC: American Psychological Association.

Hogan, J.D., \& Takooshian, H. (2004, Spring). Psi Chi, the National Honor Society in Psychology: 75 years of scholarship and service. Eye on Psi Chi, 8, 16-39. Retrieved from: www.psichi.org/ page/083EyeSpringaHogan\#.XM5mWTBKjbi

Hunt, T. (Ed.). (1979). History of Psi Chi: Fiftieth anniversary. Washington DC: Psi Chi.

Karlin, N.J. (1998). Psi Chi: encouraging excellence in psychology. Chattanooga TN: Psi Chi [9-minute video]. Retrieved from: http://youtu.be/gIKMZdNgumE

MacKinney, A.C. (Ed.). (1986). History of Psi Chi, the National Honor Society in Psychology: 1929-1986. Arlington VA: Psi Chi.

Takooshian, H., \& Newman, S.E. (1998). Recognizing excellent psychology students. International Journal of Psychology, 33, 367-369. Retrieved from: https://doi.org/10.1080/002075998400268

Tracy, C. (2000). Psi Beta. In A.E. Kazdin (Ed.), Encyclopedia of Psychology. (Vol. 6, pp. 332-333). Washington DC: American Psychological Association. 


\section{References}

Bockert, D.P. (2008, Fall). Special issue in honor of Kay Wilson. Eye on Psi Chi, 8(1), 1-56.

Carmody, D.P. (1998, Spring). Student views on the value of undergraduate presentations. Eye on Psi Chi, 2, 11-14. Retrieved from: http://www.kon.org/stud_views.html

Davis, J.M. (in press). Psi Chi Goes International. RUDN Journal of Psychology and Pedagogics.

Heitner, E. \& Denmark, F.L. (2000, Spring). The impact of Psi Chi on eminent psychologists. Eye on Psi Chi, 4(3), 14-16.

Hogan, J.D. (2001, Winter). The "other" founders of Psi Chi. Eye on Psi Chi, 5(2), 9-11.

Hogan, J.D. (2009). Ruth Hubbard Cousins (1920-2007). American Psychologist, 64(1), 48.

Lewis, F.H. (1969, Fall). Message from the first historian of Psi Chi. Psi Chi Newsletter, p. 7.

McCormick M.A., Takooshian H., Denmark F.L., del Pilar Grazioso M., Velayo R.S., Wang, A.Y., Zlokovich M.S. (2014). Building Bridges: Psi Chi and International Psychology. RUDN Journal of Psychology and Pedagogics, (4), 5-16. http://dx.doi.org/10.22363/2313-1683-2014-4-5-16

Novikova, I.A., Tarkhova, V.S., Kardashova, S.Z., \& Kharitonenko, A.A. (2019). RUDN Journal of Psychology and Pedagogics, 16(1), 101-109. http://dx.doi.org/10.22363/2313-1683-2019-16-1$88-100$

O'Roark, A.M. (2018). Footprints and visions: 75 years of the International Council of Psychologists. New York: Global Scholarly Publications.

Takooshian, H. (1994, August). Psi Chi: The impact of a student honor society on a nation's psychology. Presentation to the International Council of Psychologists, Lisbon, Portugal.

Takooshian, H. (1998, Fall). Presidential message \#1: Seventy years young. Eye on Psi Chi, 3(1), $55-56$.

Takooshian, H. (1999, Spring). Presidential message \#3: What is your Psi-Q? Eye on Psi Chi, 3(3), 67-68. Retrieved from: www.psichi.org/general/custom.asp?page=033EyeSpr99hTakooshi\#. XM3S6zBKjbg

Takooshian, H. (2013, Fall). Psi Chi International Ambassadors, 2013. International Psychology Bulletin, $17(4), 13-14$.

Takooshian, H., \& Bais, A.M.S. (2017, Winter). A pre-history of the APA Division of International Psychology. International Psychology Bulletin, 21(1), 11-13.

Takooshian, H. \& Salovey, P. (2004, Nov.). Psign of the times. APS Observer, 17(11), 23-24. Retrieved from: https://www.psychologicalscience.org/observer/psign-of-the-times

Takooshian, H., Velayo, R.S. \& Prohaska, V. (2002, Spring). Funding undergraduate research. Eye on Psi Chi, 6, 34-35.

Van Rossen, E., McCaslin, S., Owusu-Banahene, N.O., \& Wiking, M.G. (2003, Winter). The International Psychology Students' Organization (IPSO). Eye on Psi Chi, 7(2), 26-27. Retrieved from: www.psichi.org/page/072EYEWin03eRossen\#.XL0sFzBKjbg

Wang, A.Y. (2010, Fall). Report to Psi Chi members. Eye on Psi Chi, 15(1), 6.

Wilson, K., \& Bockert, D.P. (1991). Ruth H. Cousins Commemorative Issue. Psi Chi Newsletter, 17(5), $1-60$.

Young, J.R., \& DaPrada, T. (1998, Spring). Twenty-five years of the Hunter Psychology Convention. Eye on Psi Chi, 2(3), 15-17.

Zlokovich, M.S. (2010, October 14). Strategic plan for international expansion. Unpublished report. 
Zlokovich, M.S. (2012, Fall) Psi Chi and international psychology. Eye on Psi Chi, 17(1), 6. Retrieved from: www.psichi.org/general/custom.asp?page=international_histor\#.XOsDBhZKjbg

Zoma, M., \& Gielen, U. P. (2015). How many psychologists are there in the world? International Psychology Bulletin, 19, 47-50.

\title{
Article history:
}

Received: 28 April 2019

Revised: 18 May 2019

Accepted: 30 May 2019

\section{For citation:}

Takooshian, H. (2019). Psi Chi at 90 Years: The International Honor Society in Psychology. RUDN Journal of Psychology and Pedagogics, 16(2), 224-236. http://dx.doi.org/10.22363/2313-16832019-16-2-224-236

\section{Bio Note:}

Harold Takooshian, Ph.D., is Professor of Psychology, Urban Studies, and Organizational Leadership at Fordham University (USA, New York). He is Past-President of the APA Division of International Psychology (2003), and Past Officer and President of Psi Chi from 1993-2000. He was elected a Distinguished Member of Psi Beta and Psi Chi. Like thousands of others, he is deeply grateful to Psi Chi for its many impacts on his life. E-mail: takoosh@aol.com

Обзорная статья

\section{0-летие Psi Chi: Международное психологическое общество почета}

\author{
Г. Такушьян \\ Университет Фордхэм \\ Соединенные Штаты Америки, 10023, Нью-Йорк, 113 W. 60th St.
}

В 2019 году Psi Chi празднует свое 90-летие как Национальное и 10-летие как Международное психологическое общество почета. Представленный обзор славной истории Psi Chi состоит из трех частей, описывающих: 1) текущую миссию, объединяющую более 750000 пожизненных членов в 1130 отделениях по всему миру; 2) скромное, но вдохновляющее рождение в 1929 году в Йельском университете; 3) четыре вехи впечатляющей смелости в истории Psi Chi - в 1929, 1959, 1981 и 2009 годах; а также включает библиографию, с помощью которой можно подробнее познакомиться с историей Psi Chi.

Ключевые слова: Psi Chi; Psi Beta; Национальное психологическое общество почета; Международное психологическое общество почета; международная психология; история психологии

\section{История статьи:}

Поступила в редакцию: 28 апреля 2019

Принята к печати: 30 мая 2019 


\section{Для цитирования:}

Takooshian H. Psi Chi at 90 Years: The International Honor Society in Psychology (90-летие Psi Chi: Международное психологическое общество почета) // Вестник Российского университета дружбы народов. Серия: Психология и педагогика. 2019. Т. 16. № 2. С. 224-236. http://dx.doi.org/10.22363/2313-1683-2019-16-2-224-236

\section{Сведения об авторе:}

Такушьян Гарольд, Ph.D., профессор психологии, урбанистики и организационного лидерства в Университете Фордхэм (США, Нью-Йорк). Был президентом отделения международной психологии Американской психологической ассоциации (2003 г.), а также офицером и президентом Psi Chi (199-2000 гг.). Избран заслуженным членом Psi Beta и Psi Chi. Как и тысячи других, он глубоко благодарен Psi Chi за сильное влияние на его жизнь. E-mail: takoosh@aol.com 